\title{
Navigating the process of building parent-teacher partnerships: Experiences of early childhood pre-service teachers
}

\author{
Rachel Boit ${ }^{1}$
}

\begin{abstract}
This study utilized the qualitative phenomenological approach to explore pre -service teachers' experiences in their engagement with parents of young children as they practiced building partnerships with parents. Pre-service teachers $(\mathrm{N}=50)$ were each assigned a preschool child with whom they interacted together with the child's parents and teacher; completing a semester-long assignment created within a family, schools and community course for students in an early childhood teacher preparation program. Preservice teachers' responses to a survey and their final written reflections were analyzed using the process of axial and open coding. Results indicated the importance of communication and understanding different dynamics and challenges in parent-teacher partnerships. Therefore, educators should continuously strive to equip pre-service teachers with the skills they will need to succeed as they work with schools, the community and especially in their work with parents.
\end{abstract}

\section{Article History}

Received: 16 March 2020

Accepted: 11 July 2020

\section{Keywords}

Parent engagement; Preservice teachers; Teacher preparation; Early

childhood; Parent-teacher

partnerships

\section{Introduction}

Schools continuously seek to improve children's academic success and overall development. Research points to the strong association between engaging parents and children's success in school (de Bruïne et al., 2014; D’Haem \& Griswold, 2017; Epstein, 1994; Gilroy, 2018; Pemberton \& Miller, 2015; Tekin, 2011). Additionally, it is well documented that the home is a great socializing agent where the child is shaped by parental attitudes towards learning, and that parents' support plays a pivotal role in children's future school success (Harris \& Goodall, 2008). Therefore, children who receive support with their academic work at home tend to do well in school and their parents are more inclined to communicate with teachers and seek ways to better support their child at home.

Educators understand the critical role that parents play in their children's education (Mitsch, Branch, \& Weglarz-Ward, 2020) and this calls for continued efforts to build strong home-school partnerships (Buchanan \& Buchanan, 2019). Developing productive relationships with families is part of a teacher's professional role (de Bruïne et al., 2014), thus as teacher candidates embark on their professional journey, having knowledge on how to establish strong parent-teacher partnerships is critical. When pre-service teachers communicate with families, they are more likely to make informed decisions on parent engagement as well as become more aware of different family circumstances that can impact the process of building teacher-parent partnerships (Mitsch et al., 2020).

Moreover, as scholars continue to argue that developing productive relationships with families is part of a teacher's professional role, they also acknowledge that creating parent-teacher partnerships is challenging for teachers (de Bruïne et al., 2014). Further, it is worth noting that in most teacher education programs little attention is paid to preparing prospective teachers for forming these partnerships (Buchanan \& Buchanan, 2019; de Bruïne et al., 2014; Evans, 2013; Mitsch et al., 2020). Therefore, despite increased attention to family engagement in teacher education, teachers continue to feel unprepared since 
parent-teacher partnerships are not adequately addressed in ways that prepare them to work with families (Brown, Harris, Jacobson, \& Trotti, 2014). Literature addressing how teacher candidates are prepared to work with parents is scarce (Evans, 2013; Miller, Coleman, \& Mitchell, 2018) and few have focused on preservice teachers in early childhood programs. Moreover, although some studies continue to point to the important role that communication plays in parent-teacher partnerships (Buchanan \& Buchanan, 2019), few have focused on real-life experiences that offer teacher candidates opportunities to work directly with parents. Through incorporating an assignment in a child, family and community course, the current study sought to explore the experiences of pre-service teachers (enrolled in an early childhood program) in their communication with parents and their overall experiences about what it takes to form parent-teacher partnerships.

\section{Home-School Partnership Framework}

There is no one single formula or blueprint that creates a successful home-school partnership. However, there are models that provide guidelines on how to establish programs that actively involve families in their children's education (Olsen \& Fuller, 2008). One such model is Epstein's $(1995,2001,2011)$ framework that describes the home, school and community as overlapping spheres of influence where members collaborate to support children's learning and development. This model indicates that children do not learn and grow in the context of home alone or school alone but in three influential contexts- home, school and community (Olsen \& Fuller, 2008). The Family-School-Community Partnership Framework (Epstein 1995, 2011; Epstein et al., 2018) is described as a comprehensive approach that highlights the importance of the three entities working together to support children's development and education (Epstein, 1995). Although this framework has been used extensively, previous studies have acknowledged the mixed messages that this model seems to portray. For example, de Bruïne et al. (2014) and Kroeger \& Lash (2011) talk about dominant power relations where school is seen as the major force transmitting the dominant culture, thus placing teachers in a position to speak while parents listen. In hindsight, pre-service teachers will most likely encounter these relations during their field experience; therefore, during teacher preparation, it is necessary that pre-service teachers become aware of the bi-directional relationship that leads to collaboration as opposed to a power dynamic. Despite few identified weaknesses, this framework is merited for guiding family-school partnerships. Within this model, six types of family involvement are necessary for successful family-school partnerships. They are parenting, communicating, volunteering, learning at home, decision-making, and collaborating with the community (Epstein, 1995).

Parenting involves schools and communities working together to assist families with parenting and child rearing skills to support children's development and education. Parents and teachers support children's development by sharing information related to the child's development both at home and school. Both teachers and parents use this information to guide the child's learning. In communicating, schools and communities work to promote effective communication between families and teachers about children's educational progress (Coleman, 2013; Epstein, 1995). Communication between teachers and parents is not only vital for building relationships between schools and families, but also in creating a school community where families are incorporated into their children's learning (Bartels \& Eskow, 2010; Graham-Clay, 2005; Henderson \& Mapp, 2002). Specifically, Henderson and Mapp (2002) highlight that when teachers and parents have strong partnerships it improves student achievement. Successful communication between teachers and families may therefore help improve the quality of the school and programing, thus providing more opportunities for educational success (Henderson \& Mapp, 2002; Li et al., 2019). Although communication is important, unfortunately teachers are not always equipped with the training and tools needed to successfully implement effective communication practices that build strong partnerships (Bartels \& Eskow, 2010; Henderson \& Mapp, 2002). In addition, most pre-service teachers continue to indicate a need in more preparation on ways to communicate with parents (Buchanan \& Buchanan, 2019; de Bruïne et al., 2014; de Bruïne et al., 2018; Evans, 2013; Miller et al., 2018). Teacher preparation programs are therefore essential in equipping pre-service teachers with the competencies they will need to effectively engage in communication with families.

Volunteering is another key factor in parent involvement. It involves schools and communities 
working to recruit family assistance in support of children's education and parents are welcome to help with activities in the classroom, (Coleman, 2013; Epstein, 1995). When parents feel welcome by the school, they are more likely to volunteer in their children's classrooms. Learning at home is another type of involvement where schools and communities engage families in their children's learning experiences (Coleman, 2013; Epstein, 1995). However, since each family's situation is different, the way in which parents get involved in their children's schoolwork at home may vary. Thus, teachers' knowledge of circumstances that families face fosters an understanding of how to form supportive partnerships that are informed by different family contexts. Schools and communities should also involve families in making decisions about school operations (Epstein 1995); this allows them to become leaders and representatives for educational decision making and advocating for their children (Coleman, 2013). When parents understand that their voices are valued, they will be more open to participating in their children's schools. This is an easier way for teachers to tap into parent's knowledge of their role in school and their understanding of school policies, thus aiding in establishing reciprocal relationships bound by respect for everyone's opinion as opposed to power dynamics that always seem to exist between parents and teachers or school administrators.

The final form of family involvement that Epstein discusses is collaborating with the community. This type of involvement calls for schools and communities to coordinate families' access to community services to promote the total wellbeing of children. In this model, Epstein $(1995,2011)$ highlights the importance of family, school and community working together to support children's development and success in education. Most often, pre-service teachers have minimal knowledge of community services available for families in their neighborhood. Helping pre-service teachers identify these services is beneficial when they must refer families. For teachers of young children especially, having this information is important as they seek to work successfully with parents; all these begin at teacher preparation.

\section{Engaging Parents in Schools}

Education policies continue to push for mandates related to parent engagement in their programs (de Bruïne et al., 2014; Fields-Smith, 2005). In the United States of America (U.S.A.), for instance, family engagement is federally mandated under Title I of Every Student Succeeds Act of 2015 and calls for the establishment of parent partnerships with schools for the betterment of student achievement (Ford, Vakil \& Boit, 2016; Grant \& Ray, 2010). Furthermore, Goals 2000: Educate America Act of 1994 brought the importance of parent involvement to the forefront of school improvement initiatives by mandating that every school promote partnerships that increase parent engagement and participation to support the social, emotional, and academic growth of children. Additionally, the No Child Left Behind Act of 2001 required schools to organize and implement programs to engage families in their children's education in ways that help students improve skills and gain higher learning achievements (de Bruïne et al., 2014; Evans, 2013; Kroeger \& Lash, 2011).

Rigorous standards for teacher preparation programs, licensure/certification and professional practice also ensure that teachers at all levels recognize that effective teaching depends upon partnerships with children's families (Mitsch et. al, 2020). For example, in its standards for teacher preparation, the National Association for the Education of Young Children (NAEYC) specifies that "Educators know about, understand and value the importance and complex characteristics of children's families and communities" (NAEYC, 2011, p. 30). These legislative mandates clearly point to the importance of teachers promoting parent involvement in early school experiences and this emphasis needs to be an intentional component of teacher preparation programs (Mitsch et al., 2020; Taylor \& Kim, 2020).

Therefore, as theoretical and empirical perspectives support the critical role of parents in students' success, pre-service teachers too must continue receiving training on ways to engage with parents (D'Haem \& Griswold, 2017; Epstein \& Sanders, 2006; Hoover-Dempsey, Walker, Jones, \& Reed, 2002). In their work, Epstein and Sanders (2006) surveyed administrators in 161 teacher preparation programs and found that, although respondents agreed on the importance of involving families, few believed that graduating students were fully prepared to do so. Emphasizing the need for specific courses on school, family, and 
community partnerships, the benefits of family engagement in student academic and social success is highlighted (Delgado-Gaitan, 2007; Epstein, 2006; Epstein et al., 2018), and teacher educators are challenged to prepare future teachers for effective partnerships with families (D'Haem \& Griswold, 2017). In particular, the lack of preparation for pre-service teachers on how to work with families has been highlighted as being problematic and despite some progress within initial teacher preparation programs, few pre-service teachers have access to full courses on how to form partnerships with families (Willemse, Thompson, Vanderlinde, \& Mutton, 2018). It is no wonder that most pre-service teachers report learning no competencies in establishing strong partnerships with families (D'Haem \& Griswold, 2017; Patte, 2011) and often face many obstacles in achieving meaningful parent-teacher relationships (Bofferding, Kastberg, \& Hoffman, 2016). Thus, teacher education programs should consider offering at least one required course on school, family, and community partnerships (D’Haem \& Griswold, 2017; Epstein, 2001).

Additionally, pre-service teachers need to have real life encounters with parents (de Bruïne et al., 2014; Taylor \& Kim, 2020) as part of their preparation. However, evidence shows that during their professional preparation, most pre-service teachers have limited opportunities for interacting with parents (de Bruïne et al., 2014; Evans, 2013; Taylor \& Kim, 2020). This can be achieved by providing experiences where pre-service teachers interact directly with parents so they can develop skills needed for establishing effective partnerships and to give meaning to knowledge gained in the classroom (Buchanan \& Buchanan, 2019; de Bruïne et al., 2014; Mitsch et al., 2020). These interactions should take place within a prolonged period and should not be limited to only school but also to interacting at home and community. This allows them to see the complexity of parenting and realize how contextual factors can impact parent participation. In their study, de Bruïne et al. (2014) found that teacher candidates expressed a wish to have more meetings with parents at school and believed that learning by doing was the best way to further understand familyschool-partnerships. In their follow-up study, de Bruïne et al. (2018) concluded that most students wanted to accomplish their learning goals by gaining real life experiences as this would provide them opportunities for learning how to hold meaningful conversations with parents.

It is not surprising that novice teachers often report that they do not know how to effectively incorporate parents into their classrooms early in their careers (Mitsch, Branch \& Weglarz-Ward, 2020). de Bruïne et al. (2018) further advocate for curriculum changes that explore family-school-partnerships in a much more in-depth fashion but also acknowledge the challenges with large-scale changes to curricular in teacher preparation. However, substantial attention to this topic needs to begin with small scale changes that teacher educators can make in their courses; for example, adjusting course content by adding specific assignments or changing part of an already existing class activity (de Bruïne et al., 2018; Mitsch, Branch \& Weglarz-Ward, 2020; Taylor \& Kim, 2020). In many cases, real-life experiences and more authentic situations (de Bruïne et al., 2014) are not common practice and thus, the current study takes a leap in that direction.

Addressing best practices for parent engagement during teacher preparation helps teachers learn different ways of forming sustainable parent-teacher partnerships. This is especially important for early childhood pre-service teachers in that this collaboration is an essential ingredient for student learning right from the early years. Furthermore, understanding that successful early childhood education depends upon partnerships with children's families and communities, pre-service teachers in early childhood programs need to understand the complex characteristics that exist among families and communities. This aids in creating respectful, reciprocal relationships, involving families in their children's learning and development, and focusing on the educational, social and cultural aspects of home, school and community collaboration. Thus, the current work focused on experiences of preservice teachers enrolled in an early childhood teacher education course. Particularly, the goals were (a) to understand the experiences of preservice teachers in their communication process with parents and, (b) to explore their overall experiences about what it takes to form parent-teacher partnerships. Activities undertaken in this study as well as the findings and implications for teacher preparation are discussed. 
The study utilized the qualitative phenomenological approach. This methodology provides a systematic way for greater understanding of phenomena within complex contexts (Creswell, 2013). Through their written reflections and surveys, pre-service teachers provided different perspectives and meaning into parent-teacher partnerships. Data were gathered over a nine-week period during which families and pre-service teachers interacted. The sources of data were the pre-service teachers' surveys and their final written reflections. The written reflections were informed by teacher interviews, in-class observations, pre-service teacher - child interactions, family correspondence and the family and community enrichment night. For the purpose of reporting the findings, the project's proposal was approval by the university's Institutional Review Board and researchers sought permission from students to report on their work. Views from the students who accepted, are included in the findings.

\section{Setting and Participants}

This work took place at a private preschool located within an urban setting close to a public university in one of the states in the mid-western region of the United States. The preschool served families who were diverse in both their socioeconomic and racial backgrounds and offered programs for children from infancy through age 5.A total of 75 children $(0-3 y r s=16 ; 3-4 y r s=25$ and $4-5 y r s=34)$ attended the preschool. There were 9 classrooms in total; 2 for children aged 0-3 years, 3 for the 3-4-year-olds and 4 for those 4-5 years old; thus, there were 9 classrooms in total, each with a lead teacher and a teacher assistant.

In total, 44 families agreed to participate with their children. Of the 44 families, 41 each had one child participating while three families had two children each: bringing the total number of child participants to 50. Six teachers had participating families in their classrooms with the 50 children unevenly spread out into the six classrooms. Additionally, there were 50 pre-service teachers enrolled in the Child, Family, and Community course during the spring semester (course is open to all students prior to student-teaching). They were all female and 43 identified as White, five Black, one Hispanic, and one Asian. Thirty-three were in their third year in the program while 17 were in their second year. They were all in their early twenties and none of them had prior experience teaching in a preschool setting.

\section{Procedures}

Prior to starting the project, the preschool director together with the course instructor sent out a newsletter to all parents at the beginning of the semester inviting them to be part of an upcoming opportunity to engage in activities that aim at strengthening parent-teacher partnerships. The letter indicated that this was going to be a semester-long project filled with different fun activities for the children and their families. Parents also received information about pre-service teachers enrolled in the early childhood teacher preparation program, who would be interacting with the preschool children in the classrooms (guided by the teachers). Furthermore, the letter detailed the activities of the project, what parents should expect, as well as what their responsibilities and input would be. The details included (a) family correspondence, (b) pre-service teacher - child interactions and (c) family and community enrichment night. Parents who were interested signed an informed consent form and returned it to their child's teacher.

All the pre-service teachers were randomly placed in each of the six classrooms and each assigned a child with whom they would work. Families who did not give consent did not have their child assigned to a pre-service teacher and therefore whenever the preservice teachers visited the classrooms, these children continued with their regular activities with the classroom teacher. Since there were only six teachers and 50 pre-service teachers, four teachers had eight pre-service teachers placed in their classrooms, while the remaining two teachers were each assigned nine pre-service teachers. Each pre-service teacher introduced themselves to the family whose child had been assigned to them and arranged for an informal meeting. This meeting took place either at the child's preschool, at the child's home or at a playground of the family's choice. During that meeting, both pre-service teachers and families focused on establishing relationships by learning about one another. This was also an opportunity for the pre-service teachers to explain to the parents the work they were doing with their preschool children. Following this initial meeting, 
parents/guardians corresponded with the pre-service teacher on a regular basis. With permission from the parents/guardians, their contact information was shared with the pre-service teachers who were then required to communicate with the families regularly. The pre-service teachers stayed in contact with the child's family via email or messages sent in the child's folder. This lasted for nine weeks, where each preservice teacher individually worked with the preschool teachers and families of the preschoolers assigned to them.

\section{Data Collection}

Two main sources of data informed the study: namely, pre-service teachers' reflections and preservice teacher surveys.

Pre-service teachers' reflections. This comprised the written reflections submitted by the pre-service teachers at the end of the semester. Each pre-service teacher wrote a seven-page reflection paper detailing their experiences engaging with parents, preschool children and the preschool teachers. Experiences included in the reflections captured the nature of their interactions with the children, teacher interviews, family correspondence and family and community enrichment night. For each of these interactions, preservice teachers were expected to take detailed notes that would inform their reflections. The sections below describe the different activities and interactions pre-service teachers reflected on.

Teacher interviews. For each of the six classrooms, there were at least eight to nine pre-service teachers assigned depending on the number of participating families in that classroom. On one particular day during the regular course meetings, time was allocated for developing interview questions. During that time, pre-service teachers sat in groups according to the preschool classrooms they had been assigned to and brainstormed on questions to ask. Each group developed at least 8-10 questions that they thought would allow them to gain a deeper understanding of the teacher-parent interactions and the strength of their partnerships, the challenges faced by teachers in their attempt to involve parents, and ways in which teachers engaged parents in their classrooms. Some questions focused specifically on understanding how to best work with their assigned child. A sample of interview questions from one group are presented in table 1.

Table 1. Teacher interview questions

Teacher Interview

What do you see as the benefits to family and community involvement in the classroom?

What do you see as the drawback to engaging family and community members?

How do you communicate with families?

How do you help families choose how or in what ways they would like to be involved?

In what ways are the children's families involved in the child's work and what benefits of this involvement do you observe for the children?

Since there were groups of eight to nine preservice teachers assigned to one teacher, each group selected a team leader who contacted the teacher to set up the interview time. Once a time was agreed upon, the teacher and pre-service teachers met and the team leader asked the questions. During the interview, each pre-service teacher took individual notes of the teacher responses and asked any clarifying or follow-up questions which they later used to write reflections on their understanding of the teachers' views about parent-teacher partnerships.

Pre-service teacher - child interactions. Each child (whose parent agreed to participate in the project) was randomly assigned to a pre-service teacher with whom they worked for the entire project period at the preschool. During their first visit to the classroom, the pre-service teachers spent an hour conducting in-class observations of their focus child. During this activity, they took notes focusing on the child's learning styles, interaction with peers, potential challenges the child faced, and overall engagement in activities within the classroom setting. They also asked the teacher for any other information that they needed to know about their focus child. This was followed by weekly, one-hour visits of interaction with the preschool children for a total of nine hours (spread throughout the semester). During these nine onehour visits, the pre-service teachers and children worked on engaging and fun activities that were prepared by the pre-service teachers. These activities ranged from crafts, picture book reading, painting, science 
experiments, etc. At the end of each visit, the pre-service teachers put the day's work together with any work to be completed at home in a folder that was sent home to the parents and returned back to school within that week or the following week. In the folder, the pre-service teachers included a note written to the parent/guardian about what they accomplished/did not accomplish with the child and provided directions for any follow up activities to be completed at home. Pre-service teachers kept records of when and if these folders were returned, as well as records of any emails sent by the parents/guardians.

Family and community enrichment night. The project culminated with the family and community enrichment night which brought together members of the school, home and community. The family community enrichment night featured fun activities for all families served by this preschool, whether their children participated in the project or not. As a group, pre-service teachers developed a plan to host what they termed as a family and community enrichment event at the preschool. Pre-service teachers communicated with their respective families, inviting them to offer suggestions for activities or provide input into the planning. The family and community enrichment night was a firsthand experience for the pre-service teachers to engage directly with the families at the school setting. The event brought together community partners, the preschool teachers and staff, as well as the children and their families. Below is a brief description of each of the three phases undertaken in the planning process for the event.

Phase I: At this initial stage, pre-service teachers worked in groups of four or five to explore ideas for the family and community enrichment night. These included, but not limited to literacy activities, hands-on science and math learning stations, face-painting, community services and resource stations, as well as creative, sensory, and dramatic play stations. Selection of activities focused on those that aimed at providing opportunities for the pre-service teachers to engage, communicate and interact with the families. Each pre-service teacher communicated with the family they worked with to suggest activities they would like incorporated into the event.

Phase II: In partnership with the school community and the preschool director, pre-service teachers began developing plans and activities for the family enrichment night. They wrote mini proposals to outline their plans, materials required, estimated cost as well as identifying family learning goals. The day and time selected were one of two days on the preschool year calendar that had previously been allocated for "family event" and did not have a pre-planned activity. Since families already had that on their children's' calendars, the preschool director sent out reminders to all families to hold that date for a family fun night event.

Phase III: The final planning stage included pre-service teachers coordinating with partner families to promote attendance as well as finalize all details and materials. With the help of the parents and teachers, pre-service teachers developed activity stations in the various classrooms where children and their families would visit. Resources and materials needed were secured and attendance or information contribution by community resource persons was confirmed. Finally, arrangements were made to confirm guests, representatives from various community agencies or networks, and every effort made to ensure attendance from students and families. All planning was completed 10 days prior to the date set for the event.

Pre-service teacher surveys. The course instructor developed a short survey which was completed by each pre-service teacher at the end of nine weeks. Each one of them was expected to give a detailed account of their experiences with the semester-long project. Table 2 below contains a list of the survey questions.

Table 2. Survey questions

Pre-service teacher survey questions

What did you take away from this experience?

How did this experience contribute to your knowledge of building teacher-parent partnerships?

How did this experience contribute to your knowledge of families?

What else do you wish to learn that this experience did not provide? 


\section{Analysis}

Pre-service teachers' responses to the survey together with their final written reflections were read and analyzed using the process of axial and open coding (Corbin \& Strauss, 2008). Analyses were done on responses from 27 pre-service teachers who gave permission for their work to be used in this study (there was no penalty on students who did not want their work to be use in the study). First, all the 27 written reflections were read carefully to ensure they covered all the areas of the project's focus. Out of those twenty-seven, nine were found to have omitted at least one or two of the focus areas; they were deemed incomplete and therefore not included in further analysis. The remaining eighteen were read a second time to identify common codes emerging from the written reflections.

To capture thoughts from the same participants, survey responses from the eighteen pre-service teachers whose reflections were analyzed, were included in the next step of analysis. The survey responses were each read carefully and once again any new codes that emerged were recorded. Overall, examples of the codes generated include, communicating with parents, challenges in engagement, parent availability, teacher-parent relationship, parent expectations, school expectations and relationship building. Emerging themes were then created, and codes assigned to the new themes. Findings are presented in the section that follows.

\section{Findings}

This project focused on the extent to which pre-service teachers in a teacher education course gained a deeper understanding of parent involvement through real life experiences working directly with families of young children. The goals for this project were (a) to understand the experiences of pre-service teachers in their communication process with parents and, (b) to explore pre-service teachers' experiences in what it takes to form parent-teacher partnerships.

Results indicated that; (1) pre-service teachers acknowledged the power of communication as a critical skill in the process of cultivating good relationships between teachers and parents, (2) pre-service teachers saw firsthand the multidimensional challenges that both teachers and parents face in their attempts to form strong teacher-parent partnerships, and (3) pre-service teachers reported on how the project shaped them as they prepared to engage parents in their future teaching careers. Below are the findings presented under three themes.

\section{The Power of Communication in Cultivating Good Parent-Teacher Partnerships}

All pre-service teachers agreed that communication is the most important factor when cultivating relationships with families. They also acknowledged the importance of the content and the way to convey information as critical. Therefore, it is not just communicating for the sake of it, but more attention needs to be paid to the detail of that communication. Epstein (1994) posits that parents are eager to help their children if schools will help them understand what they should do. Parents are also interested in knowing what goes on in their children's classrooms and therefore communication between the teachers and the parents is paramount in becoming partners in children's education (Bofferding et al., 2016). The kind of information sent out to parents, how conversations with parents are held, and all kinds of interactions must be clear as ensuring two-way communication between home and school is key (Grant \& Ray, 2010).

Most of the pre-service teachers were young adults (between the ages of 19-21) and recognized their own challenges in the way they use language. For many of them, using certain words or phrases to substitute for standard English words is very common in their communication and as they started communicating with the families, they began to realize that the way one uses language matters. One preservice teacher noted:

"... I learned that it is sometimes difficult to find just the right words to use when telling them about their child. Even when I was not saying anything negative, I needed to be aware not to use slang words. I do not think a teacher should use slang words in general, but I felt especially strongly about using very clear language with my student's family...." 
Moreover, being clear in what teachers communicate to parents is important (Grant \& Ray, 2010). It is sometimes possible for a teacher to assume that parents are ignoring their messages or that parents do not want to communicate; this misunderstanding could be a result of parents not understanding the information. Another pre-service teacher noted that:

"I learned that you have to be clear in what you would like the parents to do. I know I would have gotten more activities completed with the family if I had asked more directly for what needed to be done rather than ask in a manner that allowed them to choose not to complete or return activities... I think it's really important for teachers to be very direct and concise about what they are expecting families to do while still being very respectful."

Intentionality and clear expectations are key if parents are to be involved. It is good practice for teachers to set goals and not merely send information home to parents without being specific about what is needed.

Murray, McFarland-Piazza and Harrison (2014) note that educators should "create a welcoming environment where all children and families are respected and actively encouraged to collaborate in curriculum decision making with educators to ensure that learning experiences are meaningful", and educators and families should "communicate freely and respectfully with each other" (p. 2). Facilitation of parent involvement and the development of supportive relationships and respectful communication with families are key features in quality early childhood teacher preparation. Quality preparation allows pre-service teachers to learn and utilize different communication preferences for families in order to facilitate communication with parents.

When parents know that their voices are heard in decision making, they feel encouraged to work closely with the teachers and school. This makes parents feel more involved and connected to their child's school experiences and their child's school life and for the teachers, they get to know about the child's home life. Being respectful to families and encouraging their collaboration was also brought up by pre-service teachers as one of the factors determining the extent to which partnerships are created and maintained. This is in line with Epstein's (1995) notion of collaborating with families so they feel that they are part of the larger community.

Pre-service teachers acknowledged the experiences gained while undertaking this assignment. They especially noted that they learned more about parents and ways to best communicate with them. For all of them, this was the first time that they had ever been afforded an opportunity to work directly with parents. In her reflection, one pre-service teacher summed up her thoughts:

"During the nine weeks I spent with the child and corresponding with his family, I learned a lot about family involvement and communication...this was the first time I have ever been required to interact not just with the student but with their family in a direct way."

\section{Challenges in Parent Engagement}

During their interaction with families, pre-service teachers became aware of the myriad of circumstances that may place families in situations that present challenges in their ability to be more involved in their children's schooling and school activities. These may range from workplace demands (i.e. having to work for long hours or sometimes conflicting schedules to family demands), a lack of transportation to merely not knowing what the school expects from them. The statements below sum up the thinking of some pre-service teachers:

“...many family members work during the day, so they are unable to come to the classroom to participate in that manner and this does not mean they are uninterested in their child's education..."

Another teacher candidate offered a different perspective about how teachers sometimes view families negatively and easily reach conclusions about their participation. As pre-service teachers interacted with families, they understood the importance of getting to know families well in order to avoid making wrong judgements. In one statement, one pre-service teacher noted:

\footnotetext{
“...as a teacher, I learned a lot from this process...I learned that parents may be involved but may just not have the time to communicate as much with the teacher...I recommend that we do not judge a family before really getting to know them...you may have a preconceived notion about them, but you could be completely wrong..."
} 
Rather than pointing to weaknesses in parent involvement, one teacher who participated in the teacher interviews seemed to see the high level of involvement of some parents and the complete lack of involvement of other parents as natural. While this teacher would likely see it as positive if each learner's parents attended some or all the available events, she understood that the home and work life of some parents prohibited their involvement. She did not seem to label or speak negatively of these parents. Other teachers pointed to a lack of resources (time, financial resources, and educational resources) as reason for the lack of involvement (both in school and at home) of some parents. These teachers did not blame parents, but rather explained their circumstances as contextual. This discussion provided a rich learning opportunity for the pre-service teachers.

While volunteering in their children's classrooms is always encouraged, parents may not always find the time to volunteer due to certain contextual factors that may hinder participation. One of them noted:

"...I learned from this experience that while family members may sometimes not help or volunteer in the classroom, they typically really enjoy getting to see their child's educational environment and meet with the child's teacher during other school events...during the family enrichment night, I witnessed several parents volunteering at different stations..."

Interactions with the children in the classroom and during the family enrichment night event proved to be powerful learning experiences for the pre-service teachers. They witnessed families take pride in their children's activities and most of them offered to help at different stations. This is an affirmation that parents are willing to volunteer in the classrooms but may not do so due to other commitments. It is also true that parents may not volunteer due to a lack of intentional commitments on the part of the teachers to welcome parents into the classrooms.

\section{Deeper Understanding of Relationship Building}

All pre-service teachers agreed that the opportunity to work with families allowed them to learn how to connect and build relationships with families. Coleman (2013) affirms that demonstrating a commitment to family-teacher relationships is one of the professional standards that teachers will be expected to demonstrate and in fact, their commitment to children will in part be judged by their commitment to the children's families. As such, future teachers should be passionate about conveying a strong sense of commitment to the students and their family's involvement. When teachers and families work together, the children are more likely to become successful in their academic pursuits. The statements below were common among the pre-service teachers:

"...this course project has made me realize how important family involvement is in the school setting...the experience gave me a good idea of what it will be like working with families and getting them involved..."

“...As a teacher, I will need to make sure I create a strong relationship with my students and their families so that everyone can feel comfortable...these relationships are crucial in helping the child create a bridge between school and home life..."

In terms of parents' opinions about involvement, most pre-service teachers reported that parents truly wanted to be engaged and informed about their children's progress and activities going on at school. They noted that while most parents were eager to form strong relationships with their children's teachers and schools, it was also true that for some parents it was not always possible to be this involved and they would sometimes miss activities taking place at their children's school.

Pre-service teachers indicated that the preschool teachers expressed their eagerness to have parents volunteer in their classrooms. They valued the contribution that parents and community members made and as professionals, they were not threatened by the presence of parents in their classroom. Their understanding of their students' and their parents' needs and abilities likely helped create a welcoming atmosphere in which children learned and parents engaged in activities with their children. As the preservice teachers worked with the preschool children one-on-one, they came to fully understand the child and his/her learning styles. Engaging parents via the children's folders sent home became the best channel for pre-service teachers to involve them in what their children were doing in the classroom. Most pre- 
Navigating the process of building parent-teacher partnerships...

service teachers reported that some parents sent the folders back while others did not and acknowledged that they now understood why they hardly heard back from some parents.

In summary, the preceding results indicated that pre-service teachers witnessed first-hand what it takes to establish relationships with parents. For most of them, this was the first time that they had interacted directly with families. Within the nine-week project period, most of them reported that they began to understand the challenges that parents sometimes face in their efforts to be engaged with their children's schools. They also understood the important role that communication plays in establishing and maintaining meaningful parent-teacher partnerships and the role that both play in these relationships. It is therefore vital that during teacher preparation, pre-service teachers are provided with opportunities to work directly with families.

\section{Discussion and Conclusions}

The results clearly indicate that pre-service teachers benefited from the family engagement assignment added into the course. By incorporating an assignment focusing on family-school partnerships into an early childhood course, the study utilized Epstein's (2011) framework to understand (1) the experiences of pre-service teachers in their communication process with parents and; (2) explore preservice teachers' experiences in what it takes to form parent-teacher partnerships. The pre-service teachers were able to demonstrate an understanding of what it takes to form partnerships with families, and they saw first-hand the powerful role that communication plays in parent-teacher partnerships. Although communication has always been considered important when working with families, it is also true that teachers are not always equipped with the tools needed to successfully implement effective communication practices that build strong partnerships (Bartels \& Eskow, 2010; Henderson \& Mapp, 2002).

The pre-service teachers in this study found that when communicating with parents, teachers must be clear about information being sent home. This is supported by the work of Bartels \& Eskow (2010) and Henderson \& Mapp (2002) who stress that teacher preparation programs continue to intentionally focus on the importance of communication and implementation of programs that help pre-service and in-service teachers learn how to develop lasting partnerships with families in the community. While there are multiple strategies for communicating with parents, for teachers, having interpersonal skills that make communication interactive, meaningful, and comfortable for the parents ensures that relationships are enhanced. In the current study, pre-service teachers valued interacting directly with parents since it allowed them to learn skills on how to maintain reciprocal relationships. Consistent with current literature (Mitsch et al., 2020), teacher preparation programs are essential in introducing pre-service teachers to the skills necessary to effectively engage in communication with families and more attention should be paid to equipping future teachers with skills that will be helpful as they build partnerships with families. Additionally, Taylor \& Kim (2019) did a similar study where pre-service teachers worked directly with parents and concluded that providing pre-service teachers opportunities to work directly with families as part of their educational program holds promise for the possibility of transformative learning to occur (Taylor \& Kim, 2019). Another outcome from the current study suggests that pre-service teachers did not only point to the importance of communication, but also expressed the significance in being intentional, clear, and choosing the right language when reaching out and conversing with parents. These sentiments are consistent with the thoughts of Grant \& Ray (2010), who stress that intentionality and clear expectations are vital when communicating with parents.

Furthermore, the pre-service teachers indicated that they were able to understand the families better and thus, invited them in their decision-making process about the child's learning and solicited their input towards the planning of the family enrichment night. In her work, Esptein (2018) talks about involving parents in decision-making at their children's schools. Teachers make this possible when they acknowledge parent' perspectives and allowing for their voices to be heard. As such, parents feel accepted in the school and thus, more willing to volunteer in their children's classrooms and other school activities. Henderson and Mapp (2002) further suggest providing both, the pre-service and in-service teachers with learning 
opportunities that help them connect and work with diverse populations, recognize the advantages of communicating and collaborating with families, and understand the benefits of creating respectful and inclusive relationships with families. Overall, teachers can benefit from learning to communicate and collaborate with families to ensure a continued strengthening of partnerships and to have a more positive experience in the classroom.

Evidence from the current study showed it was through their interaction with parents that preservice teachers learned about families' daily experiences, their participation in school and other activities and generally the realities of daily life challenges. In the absence of opportunities like these, pre-service teachers may not know what families go through, which sometimes leads to making assumptions and affecting the way they will relate to each family. An understanding of families' backgrounds helps teachers create stronger bonds and strive to recognize the realities that families face (Epstein, 2018; Graham-Clay, 2005). Being aware of families' needs, allows teachers to tailor their efforts into finding suitable ways of working with each individual family to support the children's learning at home.

The pre-service teachers appreciated the opportunity to interact directly with families; this was a new experience for most of them. Unfortunately, in many teacher preparation programs, the opportunity for pre-service teachers to work directly with families is limited (Mitsch et al., 2020; Taylor \& Kim, 2020). This is despite the expectation that when teachers enter the teaching profession, they should possess skills to successfully interact and involve parents in their classroom. This suggests that when it comes to parentteacher partnerships, we are asking a new generation of teachers to do a great deal in the classroom yet they may have not been prepared for it. Rohr \& He (2010) indicate that the challenge for teacher educators is to ensure that pre-service teachers leave our teacher preparation programs knowing how to effectively communicate with and involve parents of all students. Furthermore, as Epstein (2018) pointed out, parentteacher partnerships are a core professional skill and practice which requires development within any program of initial teacher education. Educators bear the responsibility for equipping our pre-service teachers with the skills they will need to succeed as they work with schools, the community, and especially with parents. This requires ongoing efforts in revising our teacher preparation curriculum to align with the best practices of parent-teacher partnerships. It may also mean that assignments that focus on such partnerships are intentionally added to the courses that pre-service teachers take before completing their program.

Engaging parents, families and communities contributes to raising the educational aspirations and attainment of young people (State Government Victoria Department of Education and Early Childhood Development, 2008). A wealth of evidence highlights parental engagement in schooling as positively influencing pupil achievement and attainment (Desforges \& Abouchaar, 2003). Epstein (2018) notes that without teachers' efforts on partnerships, many parents will continue to be limited in whether, and how, they motivate and guide their children's learning and development at every grade level. She continues to add that, most importantly, without teachers and parents working in partnership, many students will continue to be denied the support and encouragement for education that has been shown for decades to influence student success in school. Such evidence should be compelling enough to drive changes in the way teachers are prepared to work with families.

This study had some limitations; one such limitation was that parent participants were not interviewed to gather their thoughts about parent-teacher partnerships. Even though they had a meeting with the pre-service teachers at their homes or arranged for a playdate earlier in the project, the goal was not for them to be interviewed but rather to have a rapport where they and the pre-service teachers got to know one another. This assignment was also being piloted on a small scale and had its focus on the experiences of pre-service teachers; therefore, future studies should be designed to include interviewing parents. Another limitation is that the study comprised a small fraction of early childhood pre-service teachers enrolled in a teacher preparation program in one university; all of whom were female and mostly white. These results cannot therefore be generalized to a larger population. A similar study with a more diverse group of participants is warranted. 
Navigating the process of building parent-teacher partnerships...

Building successful parent-teacher partnerships is a process that takes a long time. It is built through trust in a dual communicative relationship. As teacher preparation programs strive to continue preparing pre-service teachers for these partnerships, there should be concerted efforts at every local and state education departments to put in place policies that require and support the promotion of parent engagement at all grade levels. Without doubt, parent engagement in children's learning makes a difference and remains one of the most powerful school improvement levers that we have (Harris \& Goodall, 2008). Parents should be encouraged to be a part of their children's education and as such it calls for a strong team of educators who are committed to making this happen. We know that pre-service teachers and novice teachers need to work together with parents, however, for this relationship to be productive teachers need to be confident in their abilities to involve parents. Building such confidence must begin at our teacher preparation programs.

\section{Declarations}

Acknowledgements I wish to thank the pre-service teachers for allowing their work to be included in this study. I also wish to thank the parents, preschool children, and their teachers together with the director of the preschool setting where this work took place.

Competing interests: There are no competing interests.

Funding: There was no funding associated with this work.

\section{References}

Bartels, S. M., \& Eskow, K. G. (2010). Training school professionals to engage families: A pilot university/state department of education partnership. School Community Journal, 20(2), 45-71.

Bofferding, L., Kastberg, S., \& Hoffman, A. (2016). Family mathematics nights: An opportunity to improve preservice teachers' understanding of parents' roles and expectations. School Science \& Mathematics, 116(1), 17-28. https://doi.org/10.1111/ssm.12109

Brown, A., Harris, M., Jacobson, A., \& Trotti, J. (2014). Parent teacher education connection: preparing preservice teachers for family engagement. The Teacher Educator, 49(2), 133-151. https://doi.org/10.1080/08878730.2014.887169

Buchanan, K. \& Buchanan, T. (2019). Preparing teacher candidates to collaborate with families and communities: Standards, research, and practice. Northwest Journal of Teacher Education, 14(1) Article 6. https://doi.org/10.15760/nwjte.2019.14.1.6

Coleman, M. (2013). Empowering family-teacher partnerships: Building connections with diverse communities. Los Angeles: Sage.

Corbin, J., \& Strauss, A. (2008). Basics of qualitative research: Techniques and procedures for developing grounded theory (3 ${ }^{\text {rd }}$ ed.). Los Angeles: SAGE. https://doi.org/10.4135/9781452230153

Creswell, J. W. (2013). Qualitative inquiry \& research design: Choosing among five approaches (3rd ed.). Thousand Oaks, CA: SAGE.

de Bruïne, E. J., Willemse, T. M., D'Haem, J., Griswold, P., Vloeberghs, L., \& Van Eynde, S. (2014). Preparing teacher candidates for family-school partnerships. European Journal of Teacher Education, 37(4), 409-425. https://doi.org/10.1080/02619768.2014.912628

de Bruïne, E., Willemse, T. M., Franssens, J., van Eynde, S., Vloeberghs, L., \& Vandermarliere, L. (2018). Small-scale curriculum changes for improving preservice teachers' preparation for Family-School Partnerships. Journal of Education for Teaching, 44(3), 381-396. https://doi.org/10.1080/02607476.2018.1465667

Delgado-Gaitan, C. (2007). Fostering Latino parent involvement in the schools: Practices and partnerships. In Paik, S. J. \& Walberg, H. J. (Eds.). Narrowing the achievement gap: Strategies for educating Latino, Black, and Asian students. (pp.17-32). NY: Springer https://doi.org/10.1007/0-387-44611-7 2

Desforges, C., \& Abouchaar, A. (2003). The impact of parental involvement, parental support and family education on pupil achievements and adjustment: A literature review (Research report, no. 433). Nottingham: DfES.

D'Haem, J., \& Griswold, P. (2017). Teacher educators' and student teachers' beliefs about preparation for working with families including those from diverse socioeconomic and cultural backgrounds. Education and Urban Society, 49(1), 81-109. https://doi.org/10.1177/0013124516630602

Epstein, J. L. (1994). Family math that's above average. Take-home activities for kids and their parents. Instructor, 103(8), 17-18. https://doi.org/10.1080/08924562.1994.11000285

Epstein, J. L. (1995). School-Family-Community Partnerships: Caring for the children we share. Phi Delta Kappan, 76(9), 701-712.

Epstein, J. L. (2001). School, family, and community partnerships: preparing educators and improving schools (1st ed.). Philadelphia: Westview Press.

Epstein, J. L. (2011). School, Family, and Community Partnerships: Preparing Educators and Improving Schools (2nd ed.). Philadelphia: 
Westview Press.

Epstein, J. L. (2018). School, family and community partnerships in teachers' professional work. Journal of Education for Teaching, 44(3), 397-406. https://doi.org/10.1080/02607476.2018.1465669

Epstein, J. L., \& Sanders, M. G. (2006). Prospects for change: Preparing educators for school, family, and community partnerships. Peabody journal of Education, 81(2), 81-120. https://doi.org/10.1207/S15327930pje8102 5

Epstein, J. L., Sanders, M. G., Sheldon, S., Simon, B. S., Salinas K. C., Jansorn, N. R., ...Williams, K. J (2018). School, family, and community partnerships: Your handbook for action ( $4^{\text {th }}$ ed.). Thousand Oaks: Corwin Press.

Evans, M. P. (2013). Educating preservice teachers for family, school and community engagement. Teaching Education, 24(2), 123-133. https://doi.org/10.1080/10476210.2013.786897

Every Student Succeeds Act. (2015, 10 December). Public Law (114-95) [Sec. 1010: Parent and Family Engagement]. Retrieved March 11, 2020 from https://www.congress.gov/114/plaws/publ95/PLAW-114publ95.pdf

Fields-Smith, C. (2005). African American parents before and after Brown. Journal of Curriculum and Supervision, 20(2), 129-135.

Ford, B., Vakil, S., \& Boit, R. (2016). Family engagement within inclusive settings. In Bakken, J. \& Obiakor, F. (Eds.), General and special education inclusion in an age of change: Roles of professionals involved. (pp. 75-98) (Advances in Special Education, 32). West Yorkshire: Emerald Publishing. https://doi.org/10.1108/S0270-401320160000032006

Gilroy, P. (2018). Preparing pre-service teachers for family-school partnerships. Journal of Education for Teaching, 44(3), 251-251. https://doi.org/10.1080/02607476.2018.1465522

Goals 2000: Educate America Act. (1994, 31 March). Public Law (103-227). [Sec. 102. National Education Goals]. Retrieved August 3 , 2019 from https://www2.ed.gov/legislation/GOALS2000/TheAct/sec102.html

Graham-Clay, S. (2005). Communicating with parents: Strategies for teachers. School Community Journal, 15(1), 117-129.

Grant, K. B. \& Ray, J.A. (2010). Home, school, and community collaboration: Culturally responsive family involvement. Thousand Oaks, CA: Sage.

Harris, A., \& Goodall, J. (2008). Do parents know they matter? Engaging all parents in learning. Educational Research, 50(3), 277-289. https://doi.org/10.1080/00131880802309424

Henderson, A., \& Mapp, K. (2002). A new wave of evidence: The impact of school, family, and community connections on student achievement. Annual Synthesis. Texas: National Center for Family \& Community Connections with Schools (SEDL).

Hoover-Dempsey, K., Walker, J., Jones, K., \& Reeds, R. (2002). Teachers Involving Parents (TIP): Results of an in-service teacher education program for enhancing parental involvement. Teaching and Teacher Education, 18(7), 843-867. https://doi.org/10.1016/S0742-051X(02)00047-1

Kroeger, J., and M. Lasch. (2011). Asking, listening, and learning: Toward a more thorough method of inquiry in home school relations. Teaching and Teacher Education 27(2), 268-277. https://doi.org/10.1016/j.tate.2010.08.010

Li, G., Lin, M., Liu, C., Johnson, A., Li, Y., \& Loyalka, P. (2019). The prevalence of parent-teacher interaction in developing countries and its effect on student outcomes. Teaching and Teacher Education, 86, 102878. https://doi.org/10.1016/j.tate.2019.102878

Miller, G., Coleman, J., \& Mitchell, J. (2018). Towards a model of interprofessional preparation to enhance partnering between educators and families. Journal of Education for Teaching, 44(3) 353-365. https://doi.org/10.1080/02607476.2018.1465660

Mitsch, M., Branch, J., \& Weglarz-Ward, J. (2020). Integrating family content in teacher preparation programs using intentional reflection and planning. Journal of Early Childhood Teacher Education, 41(2), 197-208. https://doi.org/10.1080/10901027.2020.1740843

Murray, E., McFarland-Piazza, L., \& Harrison, L. J. (2014). Changing patterns of parent-teacher communication and parent involvement from preschool to school. Early Child Development and Care, 185(7), 1031-1052. https://doi.org/10.1080/03004430.2014.975223

National Association for the Education of Young Children. (2011). 2010 NAEYC Standards for initial and advanced early childhood professional preparation programs [PDF Document]. Retrieved October 22, 2019 from https://www.naeyc.org/sites/default/files/globally-shared/downloads/PDFs/our-work/higher-ed/NAEYC-ProfessionalPreparation-Standards.pdf

No Child Left Behind Act. (2002, 8 January). Public Law (107-110). [Sec. 501: Innovative programs and parental choice provisions]. Retrieved March 11, 2020 from https://files.eric.ed.gov/fulltext/ED556108.pdf

Olsen, G., \& Fuller, M. (2008). Home-School relations: Working successfully with parents and families. Boston: Pearson.

Patte, M. (2011). Examining preservice teacher knowledge and competencies in establishing family-school partnerships. The School Community Journal, 21(2), 143-159.

Pemberton, K., \& Miller, S. (2015). Building home-school relationships to enhance reading achievement for students from families 
Navigating the process of building parent-teacher partnerships...

with limited financial resources. Education and Urban Society, 47(7), 743-765. https://doi.org/10.1177/0013124513508979

Rohr, J., \& He, Y. (2010). Preservice teachers and parents: Using a reading course to change perceptions and practice. Educational Studies, 36(1), 35-45. https://doi.org/10.1080/03055690903148530

State Government Victoria Department of Education and Early Childhood Development. (2008). Families as partners in learning $\begin{array}{llllll}\text { [PowerPoint } & \text { Slides]. } & \text { Retrieved } & \text { December } & \text { 12, 2019, } & \text { from }\end{array}$ http://www.education.vic.gov.au/Documents/school/principals/community/fapilppfamilies.ppt

Taylor, L., \& Kim, K. (2020). Experiencing the real context between families, schools, and community relationships: transforming preservice teachers' perceptions. Journal of Early Childhood Teacher Education, 41(1), 18-28. https://doi.org/10.1080/10901027.2018.1514334

Tekin, A. K. (2011). Parent involvement revisited: Background, theories, and models. International Journal of Applied Educational Studies, 10(2), 1-13.

Willemse, T.M., Thompson, I., Vanderlinde, R., \& Mutton, T. (2018). Family-school partnerships: a challenge for teacher education. Journal of Education for Teaching, 44(3), 252-257. https://doi.org/10.1080/02607476.2018.1465545 